\title{
Implementasi Pembelajaran Fisika Berbantuan Media Simulasi PhET untuk Meningkatkan Hasil Belajar Siswa Pada Materi Listrik Dinamis
}

\author{
Pendi Sinulingga $^{1, \mathrm{a})}$, Theo Jhoni Hartanto ${ }^{1, \mathrm{~b})}$, Budi Santoso ${ }^{2, \mathrm{c})}$ \\ ${ }^{1}$ Prodi Pendidikan Fisika, Universitas Palangka Raya, Jl. H. Timang, Kota Palangka Raya 73112. \\ 2SMA Negeri 1 Palangka Raya, Jl. AIS Nasution, Kota Palangka Raya 73112. \\ Email: a)pendi.sinulingga@gmail.com, ${ }^{\text {b) }}$ sisohartanto@gmail.com, ${ }^{\mathrm{c}}$ budi_sma1paray2010@yahoo.co.id
}

\begin{abstract}
This research was classroom action research that intended to improve student learning outcomes in Class X-1 SMA Negeri 1 Palangka Raya in Academic Year 2015-2016 on the dynamic electrical material. Dynamic electrical material in these research related to Ohm's Law and Electric Circuits Direct Current. The study consisted of two cycles, each cycle consisting of one meeting. Preliminary identification carried with the initial tests indicate that there are still many potential incorrect understanding of the concepts of voltage, electric current, and the concept of direct current electrical circuits.In the first cycle, learning outcomes showed that the average value was 72.35 and $85.29 \%$ of students reached the KKM. In these cycle still found students' understanding was wrong. In the second cycle, learning outcomes showed that the average value was 76.97 and $89.47 \%$ of students reached the KKM. In this cycle many students who has an understanding that got it right. It can be concluded that learning activities with the assistance of simultation PhET be able to improve student learning outcomes in Class X-1 SMA Negeri 1 Palangka Raya.
\end{abstract}

Keywords: simulation media PhET, physical learning,dynamics electricity.

\begin{abstract}
Abstrak
Penelitian ini merupakan penelitian tindakan kelas (PTK) yang dilakukan untuk meningkatkan hasil belajar siswa di Kelas X-1 SMA Negeri 1 Palangka Raya Semester Genap Tahun Ajaran 2015-2016 pada materi listrik dinamis. Materi listrik dinamis dalam PTK ini berkaitan dengan Hukum Ohm dan Rangkaian Listrik Arus Searah. Penelitian terdiri dari dua siklus yang masing-masing siklus terdiri dari satu kali pertemuan. Identifikasi awal dilakukan dengan tes awal menunjukkan bahwa masih banyak terdapat potensi pemahaman yang salah terhadap konsep-konsep tegangan, arus listrik, dan konsep rangkaian listrik arus searah. Hasil penelitian menunjukkan bahwa pada siklus I sebesar $85,29 \%$ siswa mencapai KKM, yaitu dengan rincian 29 siswa mencapai ketuntasan dan 5 siswa tidak tuntas. Nilai rata-rata pada siklus I sebesar 72,35. Namun demikian, pada pembelajaran siklus I, masih banyak siswa yang bertahan dengan pemahaman yang salah berkaitan dengan konsep tegangan listrik. Pada siklus II menunjukkan bahwa sebesar $89,47 \%$ siswa yang mencapai KKM dengan rincian sebanyak 34 siswa tuntas dan 4 siswa tidak tuntas dengan nilai rata-rata 76,97. Pada pembelajaran siklus II, banyak siswa yang sudah memiliki pemahaman konsep yang benar. Artinya, kegiatan pembelajaran dengan dibantu media PhET dapat meningkatkan hasil belajar siswa di Kelas X1 SMA Negeri 1 Palangka Raya.
\end{abstract}

Kata-kata kunci: media simulasi PhET, pembelajaran fisika, listrik dinamis. 


\section{PENDAHULUAN}

Ada dua hal yang diperoleh peneliti ketika mengamati pembelajaran IPA fisika di SMA Negeri 1 Palangka Raya, khususnya pembelajaran di kelas X-1. Pertama, pembelajaran IPA fisika melalui penerapan pembelajaran aktif lebih banyak dihindari oleh guru. Kedua, kegiatan pembelajaran lebih berpusat pada guru dimana berusaha menjelaskan materi sedangkan aktivitas siswa hanya mencatat. Kegiatan pembelajaran didominasi dengan menjelaskan, latihan menjawab soal, dan menyelesaikan tugas. Pembelajaran seperti inilah yang membawa dampak pada hasil belajar siswa di kelas X-1 SMAN 1 Palangka Raya, dimana untuk mata pelajaran IPA Fisika masih banyak siswa yang di bawah KKM.

Selain dua hal tersebut, berdasarkan hasil analisis tes awal yang diberikan oleh tim peneliti kepada siswa di Kelas X-1 SMA Negeri 1 Palangka Raya ditemukan banyak potensi miskonsepsi pada siswa. Masih banyak terdapat potensi miskonsepsi terhadap konsep-konsep tegangan listrik, arus listrik, dan konsep rangkaian listrik arus searah. Misalnya miskonsepsi model konsumsi arus, pemahaman tentang arus sebagai penyebab tegangan, dan miskonspesi tentang karakteristik rangkaian listrik arus searah. Miskonsepsi seperti ini juga pernah ditemukan di beberapa negara , diantaranya ditemukan oleh Allen (2010), Shipstone (1984), dan Engelhardt dan Beichner (2004).

Berdasarkan hasil observasi dan temuan-temuan tersebut, tim peneliti berupaya menemukan cara agar hasil belajar dan penguasaan konsep siswa di kelas X-1 SMA Negeri 1 sesuai dengan apa yang diharapkan. Salah satu alternatif pemecahan masalah tersebut adalah dengan memberikan kesempatan siswa untuk berinteraksi secara langsung melalui bantuan media dalam rangka menemukan konsep IPA Fisika. Inovasi yang dapat dilakukan untuk membantu mengatasi permasalahan pembelajaran tersebut adalah dengan menggunakan media pembelajaran (Sanjaya 2012; dan Asyhar 2012).

Kemajuan ilmu pengetahuan dan teknologi komunikasi dan informasi sangat membantu dalam menghasilkan media pembelajaran. Berbagai media interaktif telah diproduksi dan diaplikasikan oleh banyak sekolah dan lembaga pendidikan. Begitu pula halnya kegiatan percobaan sudah dapat digantikan melalui media simulasi interaktif. Melalui media simulasi interaktif ini, kegiatan percobaan dapat dikerjakan oleh siswa. Media seperti ini lebih praktis, efisien, dan relatif tidak berbahaya dibandingkan dengan laboratorium nyata (Asyhar 2012).

Dalam menyampaikan materi pembelajaran, guru pastinya akan lebih terbantu dengan menggunakan media simulasi. Khusus untuk mata pelajaran Fisika, guru sudah terbantu dengan adanya media pembelajaran berupa simulasi yang telah disediakan oleh web site khusus yaitu situs Physics Education Technology (PhET).

PhET merupakan simulasi interaktif fenomena-fenomena fisis, berbasis riset yang diberikan secara gratis. Dengan pendekatan berbasis-riset yang menggabungkan hasil penelitian sebelumnya memungkinkan para siswa untuk menghubungkan fenomena kehidupan nyata dan ilmu yang mendasarinya, pada akhirnya memperdalam pemahaman dan meningkatkan minat mereka terhadap ilmu fisika.

Proyek PhET di Universitas Colorado telah mengembangkan serangkaian simulasi yang sangat menguntungkan dalam pengintegrasian teknologi komputer ke dalam pembelejaran. Terdapat lebih dari 50 simulasi berdasarkan penelitian yang telah dilakukan sebelumnya. Simulasi tersebut terdiri dari beberapa topik fisika, kimia, bahkan matematika. Simulasi-simulasi ini mudah didapatkan, dapat dijalankan secara online dengan bantuan koneksi internet maupun dengan cara di download sehingga dapat dijalankan secara offline. Simulasi dirancang secara interaktif sehingga penggunanya dapat melakukan pembelajaran secara langsung.

PhET digunakan untuk membantu siswa memahami konsep visual, simulasi PhET menganimasikan besaran-besaran dengan menggunakan grafis dan kontrol intuitif seperti klik-dantarik, penggaris dan tombol. Dan untuk lebih mendorong eksplorasi kuantitatif, simulasi juga menyediakan instrumen pengukuran seperti penggaris, stopwatch, voltmeter dan termometer. Pada saat alat-alat ukur digunakan secara interaktif, hasil pengukuran akan langsung ditampilkan atau dianimasikan, sehingga secara efektif akan menggambarkan hubungan sebab-akibat dan representasi terkait dari sejumlah parameter percobaan (seperti misalnya gerak benda, grafik, tampilan angka dan sebagainya). 
Wieman et al (2008) menyatakan bahwa banyak dampak positif dari simulasi PhET dalam pembelajaran fisika. Beberapa dampak tersebut diantaranya: (1) simulasi PhET membuat siswa memiliki pemahaman konsep dasar IPA yang baik; (2) siswa merasa seperti seorang ilmuwan dalam belajar; (3) membuat pembelajaran lebih menarik karena sisa dapat belajar sekaligus bermain pada simulasi tersebut; dan (4) Dapat dijadikan suatu pendekatan pembelajaran yang membutuhkan keterlibatan dan interaksi dengan siswa. Baser dan Durmus (2010) menemukan bahwa penggunaan media PhET sangat efektif untuk menanamkan pemahaman konsep pada siswa pada materi listrik dinamis; menemukan bahwa peningkatan hasil belajar pada materi listrik dinamis dapat diperoleh melalui simulasi komputer melalui media PhET.

Berdasarkan uraian di atas, tim peneliti menganggap bahwa media simulasi PhET merupakan media yang baik dan tepat untuk menjadi solusi pada penelitian ini karena relevan dengan permasalahan yang ditemui. Selain itu, anggapan itu berdasarkan pertimbangan bahwa media PhET memiliki kelayakan praktis, kelayakan teknis, kelayakan biaya (Sanjaya 2012). Kelayakan praktis meliputi dapat diperoleh dengan mudah, ketersediaan sarana dan fasilitas pendukung dan keluwesan, artinya mudah dibawa kemana-mana, digunakan kapan saja dan oleh siapa saja. Kelayakan teknis berkaitan media PhET sesuai dengan tujuan pembelajaran yang ingin dicapai dan dapat merangsang terjadinya proses belajar. Selain itu, media PhET bisa di download secara gratis (kelayakan biaya).

Berdasarkan latar belakang, maka dapat tujuan penelitian ini adalah untuk mengetahui hasil belajar siswa Kelas X-1 SMA Negeri 1 Palangka Raya setelah pembelajaran IPA Fisika dengan berbantuan media PhET.

\section{METODE PENELITIAN}

Jenis penelitian yang dilakukan oleh peneliti ini adalah penelitian tindakan kelas (PTK). PTK ini merupakan proses siklus mulai tahap perencanaan, pelaksanaan tindakan, dan refleksi yang mungkin diikuti dengan perencanaan ulang (Kunandar 2013). Subjek yang digunakan dalam penelitian adalah siswa Kelas X-1 SMA Negeri I Palangka Raya yang berjumlah 38 siswa.

Agar penelitian ini dapat berjalan dengan lancar diadakan perencanaan dan langkah-langkah dengan cermat. Prosedur penelitian tindakan kelas ini menggunakan 4 tahap, yakni perencanaan, melakukan tindakan, observasi dan evaluasi. Refleksi pada siklus akan berulang kembali pada siklussiklus berikutnya. Rangkaian dari langkah-langkah dari masing-masing siklus dapat dilihat pada bagan berikut ini:

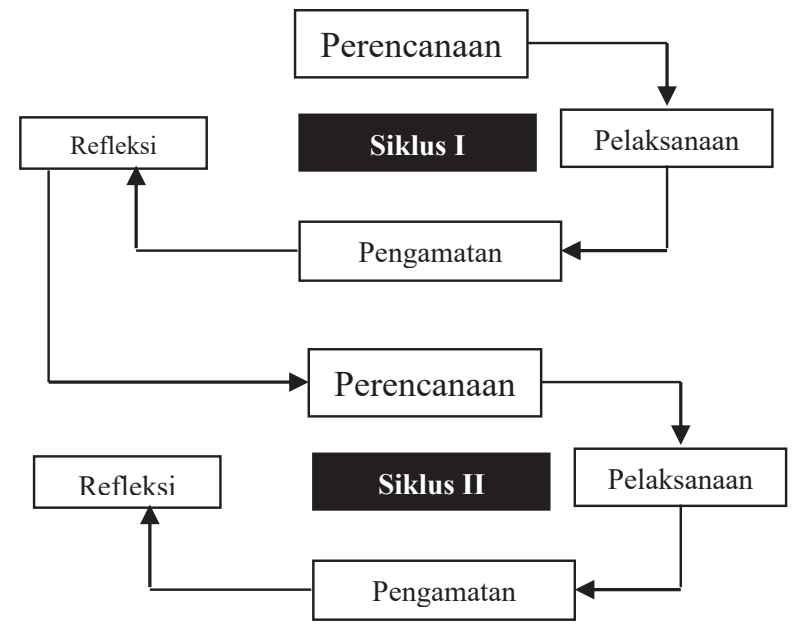

GAMBAR 1. Bagan siklus PTK

a. Perencanaan

- Menetapkan standar kompetensi dan kompetensi dasar.

- Menyusun rencana pelaksanaan pembelajaran yang akan diterapkan dalam proses belajar mengajar. 
- Menyusun LKS.

- Mempersiapkan sumber, bahan, dan alat yang dibutuhkan.

- Menyusun tes.

b. Pelaksanaan

Dalam kegiatan pelaksanaan pembelajaran ini dilaksanakan sesuai dengan skenario pembelajaran yang telah direncanakan. Dalam pelaksaan ini yang menjadi guru adalah peneliti dan yang melakukan observasi adalah teman sejawat. Dan pelaksanaannya dilakukan pada waktu pembelajaran IPA Fisika.

- Menerapkan tindakan yang mengacu pada rencana pelaksanaan pembelajaran.

- Guru memberikan kesimpulan hasil pembelajaran.

- Evaluasi berupa tes tulis penguasaan konsep.

c. Pengamatan

Melakukan observasi tentang kegiatan pembelajaran yang sudah disiapkan untuk dengan dibantu oleh teman sejawat.

d. Refleksi

- Melakukan evaluasi pelaksanaan yang telah dilakukan.

- Memperbaiki pelaksanaan tindakan sesuai dengan hasil evaluasi, untuk digunakan pada siklus berikutnya.

Data hasil tes dianalisis secara deskriptif kuantitatif-kualitatif. Untuk hasil formatif (kuantitatif) dianalisis kebenarannya sesuai dengan kunci jawaban. Langkahnya adalah memeriksa kebenaran jawaban, menyusun hasilnya pada tabel dan dan menetapkan persentase banyak siswa yang telah memenuhi KKM tersebut (KKM 70).

Sedangkan untuk analisis data secara kualitatif dilakukan dengan tahap: menyeleksi dan mengelompokkan data (reduksi data), mendeskripsikan dan memaparkan data, dan menyimpulkan atau memberikan makna dalam bentuk pernyataan.

\section{HASIL DAN PEMBAHASAN}

Sebelum pembelajaran siklus I, ditemukan bahwa masih banyak terdapat potensi miskonsepsi terhadap konsep-konsep tegangan, arus listrik, dan konsep rangkaian listrik arus searah. Potensi miskonsepsi ini diperoleh dari hasil analisis tes awal tes awal pemahaman konsep yang diberikan Tim kepada siswa di Kelas X-1 SMA Negeri 1 Palangka Raya. Tes awal ini berisi soal-soal yang berkaitan dengan konsep tegangan, arus listrik, dan konsep rangkaian listrik arus searah.

PTK dilaksanakan dalam dua siklus (siklus I dan siklus II), yang masing-masing terdiri dari empat tahap, yaitu perencanaan, pelaksanaan, observasi, dan refleksi. Adapun hasil belajar siswa kelas X1 SMAN 1 Palangka Raya pada dua siklus tersebut adalah sebagai berikut.

TABEL 1. Hasil Belajar Siswa Kelas X-1 pada Siklus I dan Siklus II.

\begin{tabular}{lccc}
\hline Siklus & $\begin{array}{c}\text { Ketuntasan } \\
\text { Individu }\end{array}$ & Ketuntasan Klasikal & Nilai Rata-rata \\
\hline Siklus 1 & $\begin{array}{c}\text { Secara individu, siswa } \\
\text { yang mencapai KKM } \\
\text { pada siklus I adalah } \\
\text { sebanyak 5 siswa tidak } \\
\text { tuntas dan 29 siswa } \\
\text { tuntas }\end{array}$ & $\begin{array}{c}\text { Secara klasikal, pembelajaran } \\
\text { pada siklus I, siswa yang } \\
\text { mencapai KKM adalah } \\
\text { sebesar 85,29\% }\end{array}$ & 72,35 \\
Siklus 2 & $\begin{array}{c}\text { Secara individu, siswa } \\
\text { yang mencapai KKM } \\
\text { pada siklus II adalah } \\
\text { sebanyak 34 siswa dan 4 } \\
\text { siswa tidak tuntas }\end{array}$ & $\begin{array}{c}\text { Secara klasikal, pembelajaran } \\
\text { pada siklus II, siswa yang } \\
\text { mencapai KKM adalah } \\
\text { sebesar 89,47\% }\end{array}$ & 76,97 \\
& & & \\
\hline
\end{tabular}

Berdasarkan pada data pada TABEL 1, terlihat bahwa pada siklus I dan siklus II, sebagian besar siswa di kelas X-1 SMAN 1 Palangka Raya sudah mencapai KKM (yaitu 70). Hasil ini mengindikasikan bahwa media simulasi PhET yang digunakan dalam pembelajaran dapat membantu meningkatkan hasil belajar siswa di kelas tersebut, terutama pada materi listrik dinamis arus searah. 
Pelaksanaan PTK pada siklus I, guru sudah melaksanakan langkah-langkah pembelajaransesuai dengan yang direncanakan, yaitu fase persiapan dan motivasi yang kemudian diikuti oleh presentasi materi pelajaran dan demonstrasi keterampilan untuk melakukan kegiatan percobaan melalui media $\mathrm{PhET}$, membimbing siswa melakukan kegiatan percobaan dengan media PhET dan memberikan umpan balik, serta memberikan kesempatan kepada siswa untuk melakukan kegiatan lanjutan. Guru memang tampak terlihat dominan dalam siklus I ini.

Berdasarkan hasil tes pada Siklus I, siswa sudah bisa menjelaskan hubungan antara kuat arus listrik dan beda potensial (tegangan) listrik (berkaitan dengan Hukum Ohm). Hal tersebut tidak terlepas dari kegiatan percobaan yang dilakukan siswa dengan bantuan media PhET. Hampir semua siswa bisa menemukan hubungan antara kuat arus listrik dan tegangan listrik. Selain itu, pada pembelajaran siklus I, untuk tes yang berkaitan dengan operasi matematika dari persamaan $V=I R$, sudah bisa diselesaikan oleh siswa. Beberapa hasil pekerjaan siswa berkaitan dengan hubungan kuat arus listrik dan tegangan listrik adalah sebagai berikut:

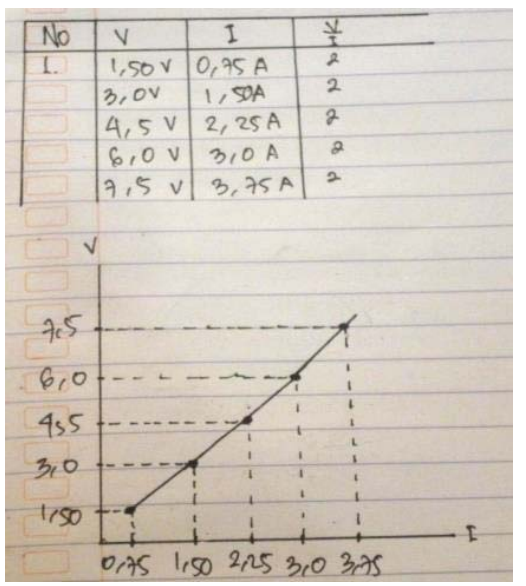

GAMBAR 2. Salah satu hasil pekerjaan siswa pada kegiatan pembelajaran siklus I pada materi Hukum Ohm.

Namun demikian, masih banyak siswa yang bertahan dengan pemahaman yang salah (miskonsepsi). Kesalahan pemahaman konsep tersebut adalah berkaitan dengan soal yang berkaitan dengan beda potensial dan disajikan sebagai berikut:

Perhatikan ragkaian di bawah ini.

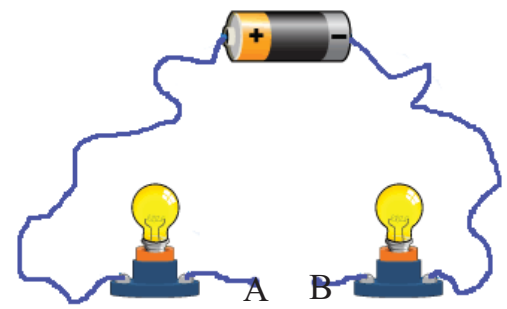

Gambar di atas menunjukkan rangkaian listrik terbuka di titik A dan B. Rangkaian terbuka tersebut terdiri dari dua lampu yang identik dan baterai $6 \mathrm{~V}$. Beda tegangan $\mathrm{AB}$ adalah ....
A. $0 \mathrm{~V}$
B. $3 \mathrm{~V}$
C. $6 \mathrm{~V}$

Ada dua jawaban siswa yang dominan berkaitan dengan soal di atas. Jawaban yang masih dominan dipilih adalah adalah A dan B dengan alasan bahwa:

- Ketika rangkaian terbuka (arus tidak mengalir) maka beda potensial antara titik A dan B juga tidak mengalir atau $\mathrm{V}_{\mathrm{AB}}=0$. 
- Beda potensial sumber tegangan sebesar 6 volt akan dibagi-bagi ke titik A dan titik B. Jadi, beda potensial di A sebesar 3 volt dan beda potensial di B juga sebesar 3 volt.

Berdasarkan hasil analisis dari pengamatan pada siklus I penelitian ini didapatkan hasil sebagai berikut:

- Walaupun sudah banyak siswa yang mencapai KKM, pada pembelajaran siklus I, masih banyak siswa yang bertahan dengan pemahaman yang salah (miskonsepsi).

- Guru masih mendominasi pembelajaran atau masih bertahan dengan pola pembelajaran sebelumnya walaupun sudah ada madia PHET. Media PhET yang seharusnya bisa mengaktifkan siswa masih belum dioptimalkan oleh guru.

Pada siklus II, berdasarkan hasil refleksi dari siklus I, suasana pembelajaran sudah mengarah kepada pembelajaran yang aktif. Tugas yang diberikan guru melalui LKS mampu dikerjakan dengan baik. siswa dalam kelompoknya menunjukkan saling membantu untuk menyelesaikan percobaan melalui media PHET. Sebagian besar siswa termotivasi untuk bertanya dan menanggapi presentasi dari kelompok yang lain.Suasana pembelajaran yang menyenangkan sudah mulai tercipta.

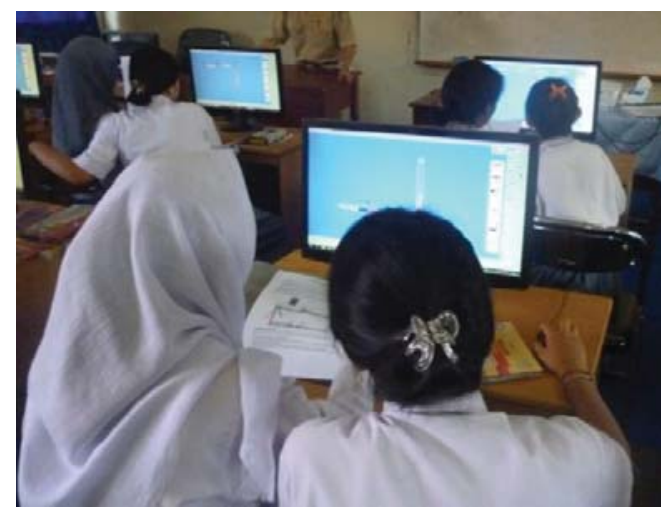

GAMBAR 3. Kegiatan pembelajaran pada siklus II.

Pada pembelajaran siklus II, banyak siswa yang sudah memiliki pemahaman konsep yang benar. Berdasarkan hasil tes, siswa sudah bisa menjelaskan konsep rangkaian arus listrik searah (seri dan paralel). Hal tersebut tidak terlepas dari kegiatan percobaan yang dilakukan siswa dengan bantuan media PhET. Hampir semua siswa bisa merangkai rangkaian seri dan paralel dan memenukan karakteristik dari masing-masing rangkaian tersebut dengan tepat. Beberapa hasil pekerjaan siswa berkaitan dengan rangkaian listrik adalah sebagai berikut:

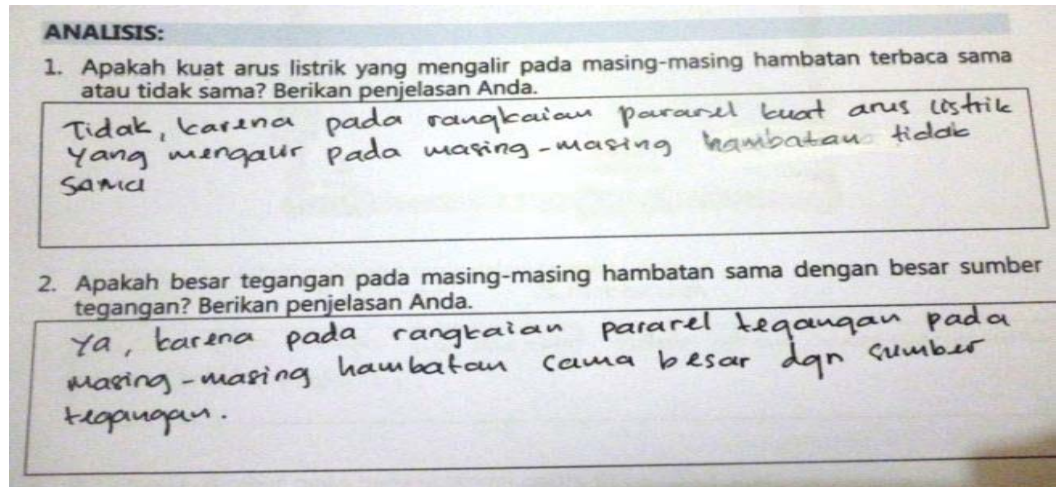

GAMBAR 4. Salah satu contoh jawaban pada konsep rangkaian paralel.

Adapun keberhasilan yang diperoleh pada siklus II ini adalah sebagai berikut:

- Ada peningkatan nilai rata-rata dari 72,35 pada siklus I menjadi 76,97 pada siklus II. Siswa yang mencapai KKM pada siklus I adalah sebanyak 10 siswa, sedangkan pada siklus II, siswa yang mencapai KKM sebanyak 29 siswa. Artinya, secara klasikal, ada peningkatan siswa 
yang tuntas pembelajaran pada siklus II, yaitu dari $29,41 \%$ siswa tuntas di siklus I menjadi $76,31 \%$ di siklus II.

- Guru tidak lagi mendominasi pembelajaran. Pembelajaran pada siklus II terlihat lebih aktif. Media PHET yang bisa dioptimalkan untuk mengaktifkan siswa.

- Hanya sebagian kecil siswa yang pemahaman konsepnya masih salah. Hasil ini seperti yang ditemukan oleh Baser (2006b) yang menemukan bahwa simulasi komputer pada materi rangkaian listrik dapat memberikan kesempatan kepada siswa untuk memperbaiki pemahamannya yang masih salah.

Selain hasil seperti yang diuraikan di atas, berdasarkan respon siswa kelas X-1 SMA Negeri 1 Palangka Raya, diperoleh bahwa penggunaan media simulasi PhET membuat pembelajaran terasa menyenangkan dan mudah dilakukan. Ini merupakan salah satu kelebihan media PhET. Simulasi yang disediakan PhET sangat interaktif yang mengajak siswa untuk belajar dengan cara mengeksplorasi secara langsung. Simulasi PhET ini membuat animasi fisika yang abstrak atau tidak dapat dilihat oleh mata telanjang, seperti aliran elektron pada kawat penghantar. Interaksi yang dilakukan berupa menekan tombol, menggeser benda atau memasukkan suatu data. Kemudian saat itu juga akibat dari interaksi yang dilakukan akan segera terlihat.

Untuk eksplorasi secara kuantitatif pada rangakian arus searah, simulasi PhET ini memiliki alatalat ukur di dalamnya seperti voltmeter dan amperemeter. Siswa tinggal memakainya untuk mengukur besaran tegangan dan kuat arus listrik. Kegiatan seperti ini benar-benar seperti memiliki laboratorium fisika sendiri, namun yang kita miliki ialah laboratorium virtual. Indikasi kemudahan menggunakan media PhET dapat di lihat dari data hasil percobaandi Gambar 5.

\begin{tabular}{|c|c|c|c|c|c|c|c|c|}
\hline \multirow[b]{2}{*}{ No. } & \multicolumn{3}{|c|}{ Kuat arus listrik (ampere) } & \multirow{2}{*}{$\begin{array}{l}\text { Kuat } \\
\text { arus } \\
\text { Total }\end{array}$} & \multicolumn{3}{|c|}{ Tegangan (ampere) } & \multirow{2}{*}{$\begin{array}{c}\text { Tegangan } \\
\text { Total }\end{array}$} \\
\hline & $\begin{array}{c}\text { Lampu } \\
1\end{array}$ & $\begin{array}{c}\text { Lampu } \\
\mathbf{2}\end{array}$ & $\underset{3}{\text { Lampu }}$ & & $\begin{array}{c}\text { Lampu } \\
1\end{array}$ & $\begin{array}{c}\text { Lampu } \\
2\end{array}$ & \begin{tabular}{|c|} 
Lampu \\
$\mathbf{3}$
\end{tabular} & \\
\hline 1. & 2 & 2 & 2 & 2 & 4 & 4 & 4 & 12 \\
\hline 2. & 1 & 1 & 1 & 1 & $A$ & 4 & 4 & 12 \\
\hline
\end{tabular}

GAMBAR 5. Salah satu contoh data hasil percobaan siswa pada percobaan rangkaian seri dengan menggunakan PhET.

Rangkuman beberapa respon siswa terhadap pelaksanaan pembelajaran ini disajikan pada TABEL 2 di bawah ini.

TABEL 2. Respon siswa terhadap kegiatan pembelajaran

\begin{tabular}{ll}
\hline \multicolumn{1}{c}{ Butir Pertanyaan } & \multicolumn{1}{c}{ Respon yang dominan } \\
\hline $\begin{array}{l}\text { Bagaimana komentar saudara terhadap } \\
\text { kegiatan pembelajaran dengan media }\end{array}$ & $\begin{array}{l}\text { Banyak siswa berkomentar bahwa dengan menggunakan media } \\
\text { simulasi PhET membuat menjadi sangat menyenangkan dan merasa } \\
\text { PhET? }\end{array}$ \\
mudah melakukan percobaan tanpa takut alat yang digunakan rusak. \\
Apakah percobaan dengan media PhET & Siswa merasa tertarik dengan percobaan menggunakan media PhET \\
menarik bagi saudara? & karena dapat melakukan percobaan rangkaian listrik dengan mudah. \\
& Siswa bisa saling berbagi dengan teman sekelompoknya dalam \\
& percoban berkaitan dengan penyelesaian masalah-masalah yang \\
dirancang dalam LKS. & \\
& Siswa berkomentar bahwa dengan percobaan media PhET mereka \\
& dapat menemukan materi-materi yang dipelajarinya, yaitu Hukum \\
& Ohm dan karakteristik rangkaian seri dan rangkaian paralel. \\
\hline
\end{tabular}

Berdasarkan TABEL 2, siswa memberikan respon yang positif terhadap kegiatan pembelajaran. Respon-respon tersebut sama seperti yang pernah ditemukan oleh Wieman et al (2008) bahwa: (1) siswa merasakan bahwa simulasi PhET sangat menyenangkan dan membantu dalam memahami isi materi pembelajaran dan (2) siswa merasakan pembelajaran dengan simulasi PhET terasa bermakna karena mereka secara aktif dapat melakukan percobaan untuk menemukan jawaban permasalahan yang diberikan guru. 


\section{SIMPULAN}

Berdasarkan hasil penelitian yang diuraikan di atas dapat disimpulkan bahwa terdapat peningkatan hasil belajar siswa pada materi listrik dinamis setelah pembelajaran dengan media PhET. Hal ini didasarkan pada hasil belajar di tiap siklus, yaitu:

- Pada pembelajaran siklus I, 85,29\% siswa berhasil mencapai KKM dengan nilai rata-rata siswa 72,35; dan

- Pada pembelajaran siklus II, 89,47\% siswa berhasil mencapai KKM dengan nilai rata-rata siswa 76,97 .

Selain itu, siswa-siswa kelas X-1 SMA Negeri 1 Palangka Raya yang mengikuti kegiatan pembelajaran ini memberikan respon yang positif terhadap kegiatan pembelajaran.

Berdasarkan hasil PTK ini, guru dapat memanfaatkan media PhET dalam membantu pelaksanaan tugas pokoknya. Materi pembelajaran dapat dibuat lebih menarik sehingga siswa akan lebih termotivasi dalam belajar. Selain itu, siswa dan guru mudah mendapatkan pengkayaan materi ajar sehingga akan meningkatkan pemahaman dan penguasaan materi tersebut. Media pembelajaran menggunakan program PhET dapat dijadikan sebagai media yang baik untuk pendidikan khususnya pada materi fisika.

\section{UCAPAN TERIMAKASIH}

Terimakasih kepada Kepala Sekolah dan staf guru fisika di SMA Negeri 1 Kota Palangka Raya dan Program Studi Pendidikan Fisika Universitas Palangka Raya yang telah membantu dalam pelaksanaan dan penyelesaian penelitian ini.

\section{REFERENSI}

Allen, Michael. Misconceptions in Primary Science. England, Open University Press, McGraw-Hill Companies (2010), p. 154-165.

Asyhar, Rayandra. Kreatif Mengembangkan Media Pembelajaran. Jakarta, Referensi (2012), p. 1-2.

Baser, M. Effects of Conceptual Change and Traditional Confirmatory Simulations on PreService Teachers' Understanding of Direct Current Circuits, Journal of Science Education and Technology, 15(5-6), (2006b), p. 367-381.

Baser, M. \& Durmus, S. The Effectiveness of Computer Supported Versus Real Laboratory Inquiry Learning Environments on the Understanding of Direct Current Electricity among Pre-Service Elementary School Teachers, Eurasia Journal of Mathematics, Science \& Technology Education, 6(1), (2010), p.47-61.

Engelhardt, P., \& Beichner, R. Students understanding of direct current resistive electrical circuits, American Journal of Physics, 72(1), (2004), p.98-115.

Kunandar. Penelitian Tindakan Kelas Sebagai Pengembangan Profesi Guru. Jakarta, Rajagrafindo Persada (2013), p.53-54.

Sanjaya, Wina. Media Komunikasi Pembelajaran. Jakarta, Kencana Prenada Media Grup (2012), p. $1-2$.

Shipstone, D. M. A study of children's understanding of electricity in simple DC circuits, European Journal of Science Education, 6(2), (1984), p.185-198.

Wieman, Carl; Adams, Wendy; Perkins, Katherine. PhET: Simulations That Enhance Learning, diunduh di www.scincemag.org (2008), p.682-683. 